\title{
Development of a single uredinium inoculation method for Puccinia kuehnii, the causal agent of sugarcane orange rust
}

\author{
Lis Natali Rodrigues Porto ${ }^{1,2}$, Alfredo Seiiti Urashima ${ }^{1}$
}

\begin{abstract}
${ }^{1}$ Universidade Federal de São Carlos, Centro de Ciências Agrárias, Via Anhanguera Km 174, CEP 13600-000 Araras, SP., Brasil, ${ }^{2}$ Undergraduate student in agriculture science

Autor para correspondência: Alfredo Seiiti Urashima (alfredo.urashima@ufscar.br)

Data de chegada: 16/06/2016. Aceito para publicação em: 26/06/2018.
\end{abstract}

$10.1590 / 0100-5405 / 181427$

\section{ABSTRACT}

Porto, L.N.R.; Urashima, A.S. Development of a single uredinium inoculation method for Puccinia kuehnii, the causal agent of sugarcane orange rust. Summa Phytopathologica, v.44, n.4, p.311-316, 2018.

The use of resistant varieties is the ideal method to control rusts. Nevertheless, knowing the pathogen's diversity is fundamental to the success of this measure. Diversity can be analyzed phenotypically and/or genotypically. For phenotypic diversity, the reaction of genotypes is assessed by means of inoculations of the pathogen generally obtained from several uredinia. One handicap of this technique is its impossibility to detect diversity among these uredinia, assuming that they are all homogenous. Therefore, the aim of the present study was to develop a single uredinium technique for Puccinia kuehnii to be used in studies of rust diversity in sugarcane. The comparison between the two inoculation methods was done by employing urediniospores from SP89-
1115 on the varieties SP89-1115 (susceptible) and RB975201 (resistant). The adopted design was completely randomized with five and seven replicates, respectively, examining incubation, latency, disease score, and injured area at 14 and 21 days. The two inoculation techniques were significantly equal for the susceptible variety, considering all evaluated parameters. For the resistant genotype, a significant difference was identified in the injured area and such difference did not interfere in the classification of the reaction of the material since values were below $1 \%$. The single uredinium technique developed in this study showed to be reliable since the genotypic profile of the inoculated fungus was similar to that of pathogens from the produced lesions.

Keywords: Saccharum spp, infection, disease, technology

\section{RESUMO}

Porto, L.N.R.; Urashima, A.S. Desenvolvimento do método de inoculação monopústula de Puccinia kuehnii, agente causal da ferrugem alaranjada da cana-de-açúcar. Summa Phytopathologica, v.44, n.4, p.311-316, 2018.

O uso de variedades resistentes é o método ideal de controle das ferrugens. Entretanto, o conhecimento da diversidade do patógeno é fundamental para o sucesso dessa medida. Essa diversidade pode ser analisada fenotipica e/ou genotipicamente. Na diversidade fenotípica, a reação dos genótipos é avaliada em inoculações do patógeno advindo geralmente de várias pústulas. Uma falha nesse esquema reside no fato de não se detectar diversidade entre essas pústulas, assumindo que todas são homogêneas. Assim, o objetivo do presente trabalho foi desenvolver a técnica de inoculação monopústula de Puccinia kuehnii a ser utilizada para os estudos de diversidade de ferrugens em cana-de-açúcar. A comparação entre os dois métodos de inoculação foi feita a partir dos urediniósporos da SP89-1115 nas variedades
SP89-1115 (suscetível) e RB975201 (resistente). O delineamento utilizado foi o inteiramente casualizado com cinco e sete repetições, respectivamente, examinando-se incubação, latência, escala de notas e área lesionada, aos 14 e 21 dias. As duas técnicas de inoculação mostraram-se significativamente iguais na variedade suscetível em todos parâmetros avaliados. Com relação ao genótipo resistente, diferença significativa foi identificada na área lesionada, diferença essa que não interferiu na classificação da reação do material, já que os valores foram abaixo de $1 \%$. O método monopústula desenvolvido deste trabalho mostrou-se confiável, pois o perfil genotípico do fungo inoculado foi similar aos dos patógenos das pústulas produzidas.

Palavras-chave: Saccharum spp, infecção, doença, tecnologia

Sugarcane is the raw material for the production of ethanol, sugar, molasse, bagasse and other products subsequently employed as sugarcane-based bioenergy, as well as fertilizer (24). Brazil is the major sugarcane producer in the world, yielding 684.8 million tons of sugarcane, with predicted production of 76.3 ton/ha for the $2016 / 2017$ crop season (11).

To reach this yield, abiotic/biotic stresses such as diseases, insect pests and droughts must be controlled during all stages of sugarcane development. Orange rust has been one of the most important threats to sugarcane production in Brazil since 2009 (4), after considerable damage to cultivar Q124 in Australia (19). Yield losses caused by this disease in Brazil have ranged from 20 to $40 \%$ tons of cane per hectare and 15 to $20 \%$ sucrose content (13). Furthermore, a survey carried out in the states of São Paulo and Mato Grosso do Sul identified that $22.6 \%$ most cultivated cultivars were susceptible or had intermediate resistant to orange rust and that the disease will remain important in the future years since $20.4 \%$ cultivars in newly established fields were susceptible $(8,9)$.

Orange rust, caused by Puccinia kuehnii, is characterized by its extraordinary capacity of dissemination by the wind, producing several disease secondary cycles in a short period, even when initiated from a tiny initial source (5). As sugarcane is cultivated in a large area in Brazil, 
overlaps with conditions favorable to the germination of urediniospores of P. kuehnii are common: 17 to $24^{\circ} \mathrm{C}$ and high humidity of 97 to $99 \%$ (20); thus, measures to keep orange rust under control are necessary to prevent epidemics.

The most important method for orange rust control is the development of resistant genotypes (14). Nevertheless, its efficacy depends on the knowledge of the pathogen's diversity since a change in the pathogen's population can determine the life span of a resistant genotype (28), a phenomenon already observed in Australia for cultivar Q124 in 2000 (19).

The phenotypic diversity of Puccinias in sugarcane has been examined through the inoculation of pathogen originated from multiple uredinia. Nevertheless, this technique is based on the premise that no uredinium presents diversity, which has not been documented (15). Therefore, single uredinium inoculation is essential for population diversity analyses, as already employed for $P$. graminis f. sp. tritici $(16,23)$. This technique has not been established for Puccinias from sugarcane, which has morphological traits different from those of the pathogen from wheat.

Thus, the present study aimed to develop a technique of single uredinium inoculation for $P$. kuehnii to be employed in diversity analyses of rust pathogens in sugarcane.

\section{MATERIAL AND METHODS}

\section{Host}

Individual buds of sugarcane cultivars SP89-1115 (susceptible control) and RB975201 (resistant control) were planted in 250-mL plastic cups containing substrate and kept at the Molecular Genetics Laboratory (LAGEM), located in the Center of Agrarian Sciences (CCA), Federal University of São Carlos (UFSCar), Araras Campus, São Paulo State, under natural photoperiod and protected from the rain, to avoid secondary infection, for 30 days.

\section{Pathogen}

Leaves of the cultivar SP89-1115 exhibiting visual symptoms of orange rust were collected at CCA $\left(22^{\circ} 18^{\prime} \mathrm{S}\right.$ and $47^{\circ} 23^{\prime} \mathrm{W}$, average altitude of $700 \mathrm{~m}$ ) and taken to the laboratory for analyses. Confirmation of orange rust was obtained under an optical microscope considering the morphological traits of urediniospores: orange, ellipsoidal, surrounded by echinulate ornamentation and presenting thickened apical wall (12).

\section{Inoculation}

Inoculations were carried out by using two different methods on the same day the disease was confirmed. The employed methods were multiple and single uredinium inoculation.

\section{Multiple uredinia method}

The inoculum suspension was prepared with urediniospores collected with a stiff-bristle brush from several uredinia on the leaf surface. The plants were individually placed in a black plastic bag, representing one replicate, and were inoculated by manually spraying a 14-mL volume, at a concentration of $1.8 .10^{5}$ spores.mL added of Tween 20 at $0.01 \%$; then, they were kept for $48 \mathrm{~h}$ at $25^{\circ} \mathrm{C}$, under watersaturated atmosphere. Subsequently, the plants were taken out of the bag and transferred to a greenhouse with natural photoperiod and humidity, but protected from rain to prevent secondary infection.

\section{Single uredinium method}

One uredinium classified as lesion type 6 according to the disease rank by Tai et al. (32) was selected. An area of $5 \mathrm{~cm}^{2}$ of the abaxial part of a leaf was previously selected and a $20-\mu \mathrm{L}$ volume of autoclaved milliQ water, added of Tween 20 at $0.01 \%$, was deposited. Then, urediniospores from the selected lesion were scattered over the water surface by using a scalpel. For the negative control, the same inoculation procedure was carried out in another area of the same leaf, employing leaf pieces of the same size but from a healthy area. Afterwards, inoculated plants were individually transferred to a plastic bag under the same conditions as those for the multiple uredinia inoculation. The concentration of the spore suspension for this method was determined by selecting lesion type 6 , retrieving urediniospores deposited in a $20-\mu \mathrm{L}$ volume with a scalpel and checking by using a hemocytometer.

\section{Evaluation}

The parameters employed to compare single and multiple uredinia inoculations were: incubation and latency periods, disease score, and percent diseased area. Incubation and latency periods were measured by taking plants to the laboratory and checking their leaves for the presence of rust symptoms under a stereomicroscope (Olympus Sz40); the check was performed daily since the end of the infection process, i.e., soon after the plants were removed from the plastic bags. The incubation period was defined as the time elapsed between the host infection by the pathogen and the first symptom, and the latency period was considered the time between the infection and the onset of reproductive structures of the pathogen (29).

Plants subjected to multiple uredinia inoculation had the entire surface of their leaves checked, whereas those that underwent single uredinium inoculation had only the inoculated area of their leaves examined, either for the positive or the negative control.

The disease rank employed by Amorim et al. (1) for brown rust of sugarcane was used for the disease score in this study, where rating $1=0 \% ; 2=0.5 \% ; 3=1 \% ; 4=5 \% ; 5=10 \% ; 6=25 \% ; 7=35 \% ; 8=$ $50 \% ; 9=>50 \%$. This scale was applied to evaluate an area of $5 \mathrm{~cm}^{2}$ leaf surface, either in the single uredinium or in the multiple uredinia inoculation, at 14 and 21 days post-inoculation. The percent injured area was assessed based on the image of the lesion area, using Assess 2.0 software (APS Press, American Phytopathological Society, St. Paul, MN, USA), for the same area employed in the disease rank.

The genotypic profiles of urediniospores of four uredinia used in the single uredinium inoculation and eight uredinia retrieved from symptoms resulted of this inoculation were compared to eliminate possible spurious contamination during the inoculation procedure. Thus, total DNA was extracted from each uredinium, according to Murray \& Thompson (27). Briefly, each uredinium was placed in a 1.5-mL microtube containing extraction buffer $(0.7 \mathrm{M} \mathrm{NaCl}, 1 \% \mathrm{CTAB}$, $50 \mathrm{mM}$ Tris- $\mathrm{HCl}$ (pH 8.0), 10mM EDTA) and 1\% 2-mercaptoetanol, where they were kept for $2 \mathrm{~h}$ at $65^{\circ} \mathrm{C}$. Subsequently, microtubes were centrifuged at $5939 \mathrm{~g}$ for $5 \mathrm{~min}$ at room temperature. A $100-\mu \mathrm{L}$ volume of the supernatant was collected, transferred to another microtube and an equal volume of chloroform:ethanol (24:1) was added, followed by homogenization for $2 \mathrm{~min}$. Then, samples were centrifuged at $15,203 \mathrm{~g}$ for $5 \mathrm{~min}$ at room temperature, $100 \mu \mathrm{L}$ supernatant were transferred to another $1.5 \mathrm{~mL}$ microtube, and $70 \mu \mathrm{L}$ isopropanol were added, homogenized and kept at $-20^{\circ} \mathrm{C}$ for $1 \mathrm{~h}$. Subsequently, the solution was centrifuged again at $15,203 \mathrm{~g}$ for $20 \mathrm{~min}$, at $4^{\circ} \mathrm{C}$, the whole volume was discarded and $1 \mathrm{~mL}$ alcohol $70 \%$ was added and centrifuged at $15,203 \mathrm{~g}$ for $10 \mathrm{~min}$, at $4^{\circ} \mathrm{C}$. After DNA washing, it was dried for $3 \mathrm{~min}$ in the 
concentrator (Eppendorf, 5301), dissolved in $20 \mu \mathrm{L}$ autoclaved milliQ water, and kept in the dark for two days before storage at $-20^{\circ} \mathrm{C}$.

PCR reaction was performed in a $10-\mu \mathrm{L}$ volume, with $10 \mathrm{mM}$ Tris-HCL, $\mathrm{pH} 8.8,50 \mathrm{mM} \mathrm{KCL}, 2.0 \mathrm{mM} \mathrm{MgCl}, 1 \mu \mathrm{M}$ each primer, $200 \mu \mathrm{M}$ dNTPs, 0.5 unit Taq DNA polymerase and $2 \mu \mathrm{L}$ DNA. The employed molecular markers were the microsatellites RST_135_B and RST_382_sptnk_a, developed for P. kuehnii by Arias et al. (2). The thermocycler BIO-RAD (C1000 Touch Thermal Cycler) was employed for DNA amplification under the following conditions: 95 ${ }^{\circ} \mathrm{C}$ for $1 \mathrm{~min}, 60^{\circ} \mathrm{C}$ for $1 \mathrm{~min}\left(2\right.$ cycles), $95^{\circ} \mathrm{C}$ for $30 \mathrm{~s}, 60{ }^{\circ} \mathrm{C}$ for 30 s, $68{ }^{\circ} \mathrm{C}$ for $30 \mathrm{~s}$ (27 cycles) and final extension of $68{ }^{\circ} \mathrm{C}$ for $4 \mathrm{~min}$. Following amplification, PCR products were visualized in agarose gel (3\%), after ethidium bromate staining, and photos were taken (Loccus Biotecnologia, L-Pix).

\section{Statistical design}

A completely randomized design was adopted for the entire experiment, with five replicates for the challenge of cultivar SP891115 , and seven for RB975201. Data were subjected to normality test and converted to $\sqrt{x+0.5}$. Tukey's test at $5 \%$ probability was applied to examine differences among treatments, using Software Assistat 4.1.

\section{RESULTS}

Incubation period of 7.5 days was observed for the susceptible cultivar (SP89-1115) in the single uredinium inoculation, varying from a minimum of 7 and a maximum of 8 days, whereas in the multiple uredinia inoculation the average was 9 days, varying from 8 to 10 days. Latency period was 9 days for the single uredinium inoculation and 10 days for the multiple uredinia. When these parameters were analyzed for the resistant cultivar (RB975201), the incubation period lasted an average of 9.5 days, varying from 9 to 10 days for single uredinium and 10.5 for multiple uredinia, a variation of 9 to 10 days. The latency period could not be observed in both inoculation methods for this cultivar since uredinium sporulation did not occur (Table 1).

Urediniospore concentration in the single uredinium inoculation was $1.10^{5}$ spores. $\mathrm{mL}^{-1}$, demonstrating that this inoculation method had the same concentration as that of multiple urenidia inoculation when this area was employed. The single uredinium inoculation in the susceptible genotype (SP89-1115) caused a disease score of 3.67 at 14 days after inoculation, whereas the multiple uredinia technique caused a lesion of 3.83 . When the same parameter was examined at 21 days post-inoculation, single uredinium led to a disease score of 4.8 and multiple uredinia to a score of 5.0. There was no significant difference between both methods, regardless of the evaluation date since the disease increase, reflected in the disease score, was similar in both methods. As to diseased area, the single uredinium inoculation resulted in an area of $3.68 \%$ at 14 days after inoculation, whereas the multiple uredinia led to an area of $3.58 \%$; at day 21 , the diseased area was 10.43 and $14.88 \%$ for single uredinium and multiple uredia, respectively. There was no significant difference in the affected area between both methods in these evaluation periods because the variation in the diseased area was proportional between dates (Table 2).

The single uredinium inoculation led to a disease score of 1.14 for the resistant cultivar (RB975201) evaluated at 14 days post-inoculation, which did not differ significantly from multiple uredinia inoculation which also caused a disease score of 1.14. The disease score at 21 days was 2.0 for single uredinium and 1.42 for multiple uredinia. The percent diseased area at day 14 was $0.10 \%$ for the single uredinium inoculation technique and $0.03 \%$ for the multiple uredinia inoculation technique, which were significantly different. The same trend occurred at day 21 , with $0.46 \%$ for the single uredinium inoculation and $0.14 \%$ for the multiple uredinia inoculation (Table 3 ).

The percent area affected by orange rust in two sugarcane cultivars according to the inoculation method assessed at 21 days after inoculation is shown in Figure 1. The single uredinium technique led to a diseased area of $6.28 \%$ in the susceptible cultivar (SP89-1115), whereas the multiple uredinia inoculation resulted in an area of $7.48 \%$. When the resistant genotype (RB975201) was examined, the single

Table 1. Reaction of sugarcane cultivars to Puccinia kuehnii in terms of incubation and latency (days), according to the inoculation method.

\begin{tabular}{ccccc}
\hline & \multicolumn{2}{c}{ SP89-1115 } & RB975201 & Incubation \\
\cline { 2 - 5 } & Incubation & Latency & 9.5 & Not observed \\
Single uredinium & 7.5 & 9 & 10.5 & Not observed \\
Multiple uredinia & 9 & 10 & & . \\
\hline
\end{tabular}

Table 2: Reaction of sugarcane cultivar SP89-1115 to Puccinia kuehnii in terms of disease score and percent diseased area, evaluated at 14 and 21 days post-inoculation, according to the inoculation method.

Disease score $^{1} \quad$ (\%) Area $\quad$ Disease score $\quad(\%)$ Area

\begin{tabular}{ccccc}
\hline Single uredinium & $3.67 \mathrm{a}$ & $3.68 \mathrm{a}$ & $4.8 \mathrm{a}$ & $10.43 \mathrm{a}$ \\
Multiple uredinia & $3.83 \mathrm{a}$ & $3.58 \mathrm{a}$ & $5.0 \mathrm{a}$ & $14.88 \mathrm{a}$ \\
\hline$(\%) \mathrm{CV}$ & 17.21 & 28.08 & 18.82 & 38.94 \\
\hline
\end{tabular}

${ }^{1}$ Amorim et al. (1987): score $1=0 \% ; 2=0.5 \% ; 3=1 \% ; 4=5 \% ; 5=10 \%$. 
Table 3. Reaction of sugarcane cultivar RB975201 to Puccinia kuehnii in terms of disease score and percent diseased area, evaluated at 14 and 21 days post-inoculation, according to the inoculation method.

days $14 \quad$ days 21

\begin{tabular}{|c|c|c|c|c|}
\hline & Disease score $^{1}$ & (\%) Area & Disease score & (\%) Area \\
\hline$(\%) \mathrm{CV}$ & 10.56 & 5.44 & 12.81 & 12.58 \\
\hline
\end{tabular}

${ }^{1}$ Amorim et al. (1987): score $1=0 \% ; 2=0.5 \% ; 3=1 \% ; 4=5 \% ; 5=10 \%$.
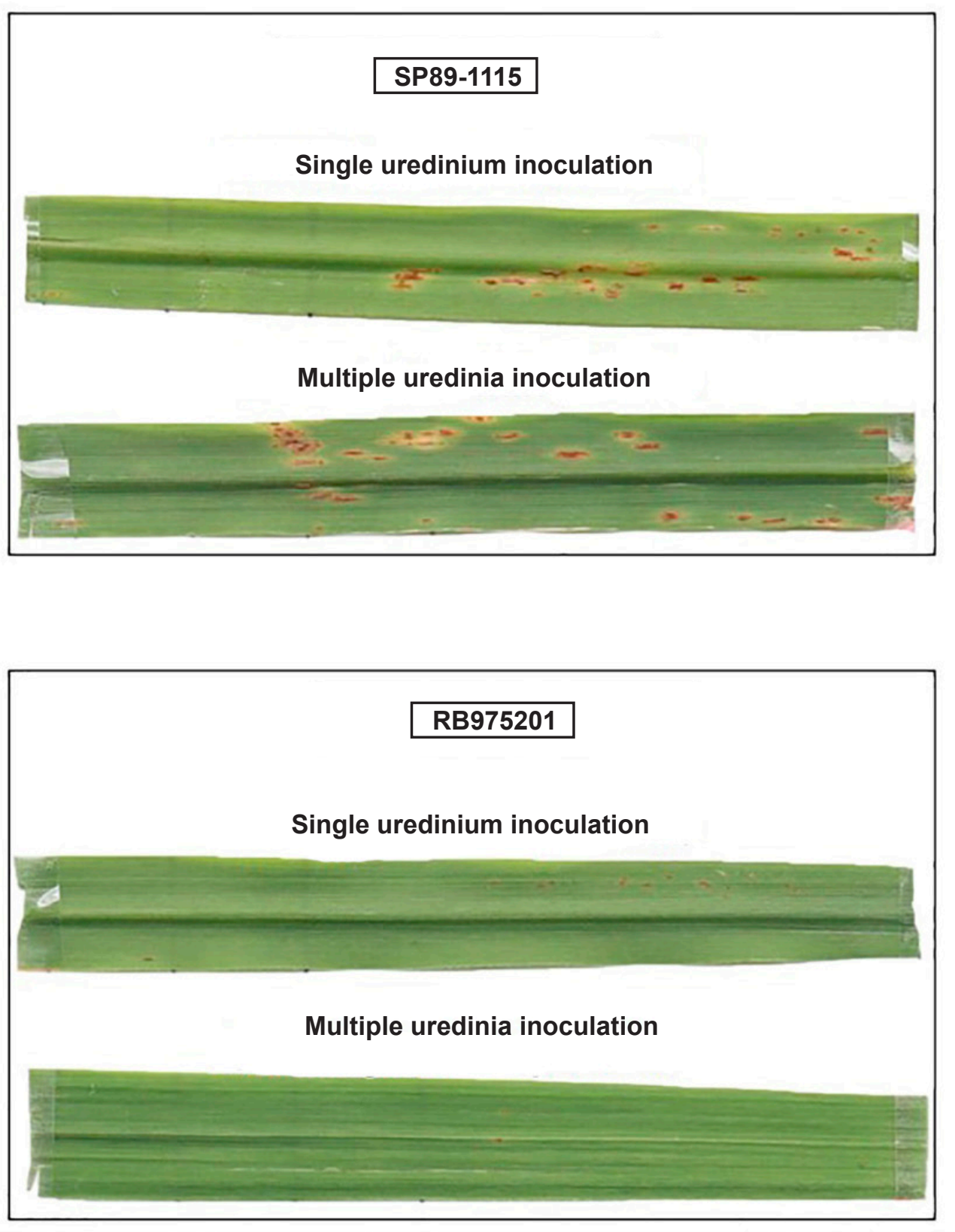

Figure 1. Reaction of sugarcane cultivars SP89-1115 and RB975201 to Puccinia kuehnii in terms of percent diseased area, evaluated at 21 days post-inoculation, according to the inoculation method. 


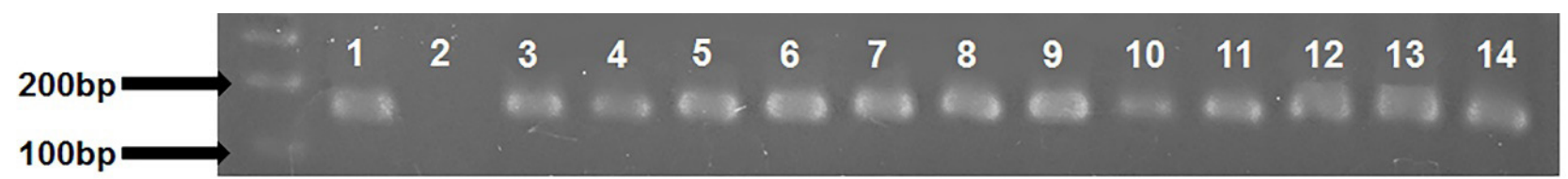

Figure 2. PCR products of Puccinia kuehnii amplified by primers RST_135_B and RST_382_sptnk_a (Arias et al., 2011). Lane 1: Positive control; 2: Negative control (water); DNA from fungus employed in the inoculation: lanes 3, 6, 10, 13; DNA retrieved from fungus isolated from symptoms: lanes $4,5,7,8,9,11,12,14$.

uredinium inoculation caused $0.41 \%$ diseased area, while the multiple uredinia, $0.07 \%$. For both inoculation methods, the distribution of uredinia occurred evenly along the inoculated surface, with no visual distinction of symptoms between both inoculation methods.

One important component to validate the single uredinium technique is the absence of contamination by unwanted uredioniospores. Therefore, a genotypic profile was employed to show that urediniospores retrieved from orange rust symptoms were similar to those used in the inoculation and caused uredinia of orange rust. As shown in Figure 2, the urediniospores used in the inoculation (wells 3, 6, 10 and 13) had the same genotypic profile as those obtained from uredinia of symptoms caused after inoculation (wells 4, 5, 7, 8, 9, 11, 12 and 14).

\section{DISCUSSION}

The obtained data showed that the single uredinium inoculation technique developed in this study can replace the multiple uredinia inoculation to examine either the diversity of P. kuehnii or the reaction of sugarcane genotypes because both inoculation methods had significantly similar results for all tested parameters (incubation and latency periods, disease score, and percent diseased area). The parameters analyzed in the comparison between methods were selected because they were used in correlated studies $(3,7,22,26)$. Nevertheless, applying the single uredinium technique developed in this study requires caution: the age of the sugarcane should be around 45 days, the area of the abaxial leaf to be inoculated should be $5 \mathrm{~cm}^{2}$, and the host reaction should be evaluated between 14 and 21 days post-inoculation, a period also employed in previous studies $(7,15,25)$.

The single uredinium inoculation technique is recommended for laboratory studies and has already been employed for $P$. graminis $\mathrm{f}$. sp. trittici and P. striiformis f. sp. hordei $(17,21)$. As to P. kuehnii, the methodology developed in this study was validated since the single uredinium inoculation exhibited the same reaction as that of multiple uredinia inoculation in two sugarcane cultivars (compatible/ incompatible) which, in turn, yielded a result similar to that of field evaluation for these two sugarcane cultivars. In the latter, host reaction to rust pathogen is visually examined based on the disease score, allowing evaluation of a great number of materials (7). According to this disease rank, the score varies from 1 to 9 , from the least to the most affected materials (1), and genotypes are classified as resistant when scores range between 1 and 3 , while scores from 4 to 9 indicate that the genotypes are susceptible (10). Sugarcane cultivars SP89-1115 and RB975201 were classified as susceptible and resistant, respectively, for both inoculation methods evaluated at 14 and 21 days (Tables 2 and 3). The significant difference in the percent diseased area for the resistant cultivar (RB975201) did not interfere in its classification as a resistant genotype since this value still fits into the range of a resistant material, which is from 0 to $1 \%(1,10)$. It is worth mentioning that genotypes classified as resistant encompass materials with varying diseased area (up to $1 \%$ ), which is an important step in the breeding process because it allows the incorporation of minor genes in a sugarcane cultivar (18). On the other hand, selection of genotypes based solely on score zero (symptomless) considers only qualitative resistance, which could eventually lead to the vertifolia effect (6), which is the erosion of horizontal resistance during the breeding process of a crop, increasing the probability of resistance breakdown for a resistant cultivar.

Single uredinium inoculation shows to be a useful tool for pathogen diversity studies, either phenotypic or genotypic studies, especially for fungi causing rust, since the efficient dissemination of urediniospores can result in multiple and varied inoculum sources even in a single leaf symptom, which could not be identified in a multiple inoculation. The single uredinium inoculation evidenced that a great number of distinct individuals initiated an outbreak of oat stem rust (P. graminis f. sp. avenae) in fields of Sweden, indicating that a large number of individuals (inoculum source) should have initiated the disease in each field and not within each field (5). This useful information could only be obtained when each pathogen was individualized by uredinium, demonstrating that the entire diversity can only be evaluated when single uredinium inoculation is employed (17).

The possibility that orange rust symptoms caused by external urediniospores mixed with those caused by the single uredinium inoculation is minimal despite efficient aerial dissemination of these spores, since low humidity was maintained throughout the host development. Moreover, the genotypic profiles of inoculated urediniospores and spores retrieved from lesions were similar, indicating absence of unwanted spores during the infection process (Figure 2).

\section{REFERENCES}

1. Amorim, L.; Bergamin Filho, A.; Sanguino, A.; Cardoso, C.O.N.; Moraes, V.A.; Fernandes, C.R. Metodologia de avaliação de ferrugem da canade-açúcar (Puccinia melanocephala). Boletim Técnico Copersucar, São Paulo. v.39, p.13-16, 1987.

2. Arias RS, Ray JD, Mengistu A, Scheffler BE. Discriminating microsatellites from Macrophomina phaseolina and their potential association to biological functions. Plant Pathology, London, v. 60, p.709-718, 2011.

3. Bade, C. I. A.; Carmona, M. A. Comparison of methods to assess severity of common rust caused by Puccinia sorghi in maize. Tropical Plant Pathology, Brasília, v. 36, n 4, p.264-266, 2011.

4. Barbasso, D.; Jordão, H.; Maccheroni, W.; Boldini, J; Sanguino, A. First report of Puccinia kuehnii, causal agent of orange rust of sugarcane, in Brazil. Plant Disease, Saint Paul, v. 94, n. 9, p.1170, 2010.

5. Berlin, A.; Samils, B.; Djurle, A.; Wirsén, H.; Zsabo, L.; Yuen, J. Disease development and genotype diversity of Puccinia graminis f.sp. avenae in Swedish oat fields. Plant Pathology, London, v. 62, p.32-40, 2013.

6. Camargo, L. E. A. Controle genético. In: Amorim, L.; Rezende, J. A. M.; Bergamin Filho, A. (Ed.). Manual de fitopatologia: princípios e conceitos. 4 ed. Piracicaba: Agronômica Ceres, v.1, p.336-337, 2011.

7. Chapola, R. G. Reação de variedades de cana-de-açúcar à ferrugem alaranjada (Puccinia kuehnii). 2013. 77f. Tese (doutorado em ciências, área de concentração: fitopatologia) - Escola Superior de Agricultura "Luiz 
de Queiroz", Universidade de São Paulo, Piracicaba.

8. Chapola, R. G.; Juniro, A. R. F.; Cursi, D. E.; Hoffmann, H.P. Censo de Variedades de Cana- de- Açúcar nos Estados de São Paulo e Mato Grosso do Sul em 2015. STAB, São Paulo, vol. 34 nº5, p.37-39, 2016.

9. Chapola, R.G.; Hoffmann, H.P.; Massola, N.S. Reaction of sugarcane varieties to orange rust (Puccinia kuehnii) and methods for rapid identification of resistant genotypes. Tropical Plant Pathology, Brasília, vol.41, p.139-146, 2016.

10. Coelho, J.A, Sordi, R.A, Casagrande, M.V.; Braga Jr., R.L.C. Reação ao carvão e a ferrugem da coleção de variedades da Copersucar I - Variedades estrangeiras. Boletim Técnico Copersucar, São Paulo 49:21-25, 1990.

11. Companhia Nacional de Abastecimento. Acompanhamento da safra Brasileira: cana-de-açúcar, safra 2016/2017, segundo levantamento, agosto de 2016. Brasília, 2016. Disponível em: <http://www.conab.gov. br/OlalaCMS/uploads /arquivos/16_08_17_10_07_35_boletim_cana_portugues - 2o lev - 16-17.pdf $>$. Acesso em: 11 jan. 2017.

12. Comstock, J.C.; Sood, S.G.; Glynn, N.C.; Shine, JR.J.M.; Mckemy, J.M.; Castlebury, L.A. First report of Puccinia kuehnii, causal agent of orange rust of sugarcane, in the United States and Western Hemisphere. Plant Disease, Saint Paul, v.92, n.1, p.175, 2008.

13. Cruz, J.C.S.; Jeronimo, E. M.; Perdoná, M. J. Informações sobre a ferrugem alaranjada da cana-de-açúcar. Pesquisa \& Tecnologia, São Paulo, vol. 11, n. 1,5 p., 2014.

14. Ferrari, J.T.; Harakava, R.; Domingues, R.J.; Terçariol, I.M.L. Ferrugem alaranjada da cana-de-açúcar. Instituto Biológico, São Paulo, 8p. (Documento técnico, 5), 2010.

15. Hoy, J.W.; Avellaneda, M.C.; Bombecini, J. Variability in Puccinia melanocephala pathogenicity and resistance in sugarcane cultivars. Plant Disease, Saint Paul, v. 98 n.12, p.1728-1732, 2014.

16. Jin, Y.; Rouse, M.; Groth, J. Population diversity of Puccinia graminis is sustained through sexual cycle on alternate hosts. Journal of Integrative Agriculture, Amsterdam, v.13, issue 2, p. 262-264, 2014.

17. Jin, Y.; Szabo, L.J.; Pretorius, Z.A.; Singh, R.P.; Fetch, T.J. Detection of virulence to resistance gene $\mathrm{Sr} 24$ whithin race TTKS of Puccinia graminis f. sp. trittici. Plant Disease, Saint Paul, 92: 923-926, 2008.

18. Klosowski, A.C.; Bespalhok Filho, J.C.; Ruaro, L.; May de Mio, L.L. Inheł ritance of resistance to orange rust (Puccinia kuehnii) in sugarcane families from crosses between parents with different orange rust reactions. Sugar Tech, Lucknow, v.15, n.4, p.379-383, 2013.
19. Magarey, R.; Willcox, T.; Croft, B.; Cordingley, A. Orange Rust, a major pathogen affecting crops of Q124 in Queensland in 2000. Proceeding Australian Society Sugarcane Technologists, Brisbane, v. 23, p.274-280, 2001.

20. Magarey, R.C.; Neilsen, W.A.; Magnani, J.A. Environmental requirements for spore germination in three sugarcane leaf pathogens. Proceeding Australian Society Sugarcane Technologists, Brisbane, v. 26, 7p., 2004.

21. Marshall, D.; Sutton, R. L. Epidemiology of stripe rust, virulence of Puccinia striiformis f. sp. hordei, and yield loss in barley. Plant Disease, Saint Paul, v. 79, n. 7, 1995.

22. Martins, T.D. Aspectos epidemiológicos da ferrugem alaranjada da canade-açúcar. 2010. 65p. Tese (Doutorado em Ciências) - Escola Superior de Agricultura "Luiz de Queiroz", Universidade de São Paulo, Piracicaba.

23. Mcvey, D. V., Nazim, M., Leonard, K. J., Long, D. L. Patterns of virulence diversity in Puccinia triticina on wheat in Egypt and the United States in 1998-2000. Plant Disease, Saint Paul, 88:271- 279, 2004.

24. Milanez, A.Y; Nyko, D.; Valente, M.S.; Sousa, L.C.; Bonomi, A.; Jesus, C.D.F.; Watanabe, M.D.B.; Chagas, M.F.; Rezende, M.C.A.F.; Cavalett, O.; Junqueira, T.L.; Gouvêia, V.L.R. De promessa a realidade: como o etanol celulósico pode revolucionar a indústria da cana-de-açúcar: uma avaliação do potencial competitivo e sugestões de política pública. BNDES Setorial, Rio de Janeiro, n.41, p. [237] -294, 2015. Disponível em: <https://web. bndes.gov.br/bib/jspui/ handle/1408/4283>. Acesso em: 13 jan. 2017.

25. Mistura, T. F. Fatores que influenciam no sucesso e longevidade do controle das ferrugens da cana-de-açúcar por variedades resistentes. 2016. 78f. Dissertação (Mestrado em produção vegetal e bioprocessos associados) - Universidade Federal de São Carlos, Araras.

26. Moreira, A.S. Ferrugem alaranjada da cana-de-açúcar no Brasil: estudo de populações do patógeno e comportamento varietal. 2013. $87 \mathrm{p}$. Tese (Doutorado em Ciências) - Escola Superior de Agricultura "Luiz de Queiroz", Universidade de São Paulo, Piracicaba.

27. Murray, M.G.; Thompson, W.F. Rapid isolation of high molecular weight plant DNA. Nucleic Acids Research, Oxford, v.8, n.19, p.4321-4325, 1980.

28. Rott, P.C.; Girard, J.C.; Comstock, J.C. Impact of pathogen genetics on breeding for resistance to sugarcane diseases. Proceeding International Society Sugarcane Technologists, Mauritius, v. 28, p.1-11, 2013.

29. Shurtleff, M.C.; Averre III, C.W. Glossary of Plant- Pathological Terms. The American Phytopathological Society, Saint. Paul, Minnesota, 1998.

30. Tai, P.Y.P.; Miller, J.D.; Dean, J.L. Inheritance of resistance to rust in sugart cane. Field Crops Research, Amsterdam, v.4, p.261-268, 1981. 